NASA/TM-2010-216341

\title{
Back-Face Strain for Monitoring Stable Crack Extension in Precracked Flexure Specimens
}

Jonathan A. Salem and Louis J. Ghosn

Glenn Research Center, Cleveland, Ohio 


\section{NASA STI Program . . . in Profile}

Since its founding, NASA has been dedicated to the advancement of aeronautics and space science. The NASA Scientific and Technical Information (STI) program plays a key part in helping NASA maintain this important role.

The NASA STI Program operates under the auspices of the Agency Chief Information Officer. It collects, organizes, provides for archiving, and disseminates NASA's STI. The NASA STI program provides access to the NASA Aeronautics and Space Database and its public interface, the NASA Technical Reports Server, thus providing one of the largest collections of aeronautical and space science STI in the world. Results are published in both non-NASA channels and by NASA in the NASA STI Report Series, which includes the following report types:

- TECHNICAL PUBLICATION. Reports of completed research or a major significant phase of research that present the results of NASA programs and include extensive data or theoretical analysis. Includes compilations of significant scientific and technical data and information deemed to be of continuing reference value. NASA counterpart of peer-reviewed formal professional papers but has less stringent limitations on manuscript length and extent of graphic presentations.

- TECHNICAL MEMORANDUM. Scientific and technical findings that are preliminary or of specialized interest, e.g., quick release reports, working papers, and bibliographies that contain minimal annotation. Does not contain extensive analysis.

- CONTRACTOR REPORT. Scientific and technical findings by NASA-sponsored contractors and grantees.
- CONFERENCE PUBLICATION. Collected papers from scientific and technical conferences, symposia, seminars, or other meetings sponsored or cosponsored by NASA.

- SPECIAL PUBLICATION. Scientific, technical, or historical information from NASA programs, projects, and missions, often concerned with subjects having substantial public interest.

- TECHNICAL TRANSLATION. Englishlanguage translations of foreign scientific and technical material pertinent to NASA's mission.

Specialized services also include creating custom thesauri, building customized databases, organizing and publishing research results.

For more information about the NASA STI program, see the following:

- Access the NASA STI program home page at http://www.sti.nasa.gov

- E-mail your question via the Internet to help@ sti.nasa.gov

- Fax your question to the NASA STI Help Desk at 443-757-5803

- Telephone the NASA STI Help Desk at 443-757-5802

- Write to: NASA Center for AeroSpace Information (CASI) 7115 Standard Drive Hanover, MD 21076-1320 
NASA/TM-2010-216341

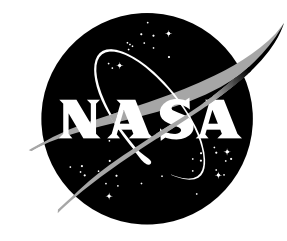

\section{Back-Face Strain for Monitoring Stable Crack Extension in Precracked Flexure Specimens}

Jonathan A. Salem and Louis J. Ghosn

Glenn Research Center, Cleveland, Ohio

National Aeronautics and

Space Administration

Glenn Research Center

Cleveland, Ohio 44135 


\section{Acknowledgments}

The authors would like to thank Ralph Pawlik for parts of the experimental work.

Trade names and trademarks are used in this report for identification only. Their usage does not constitute an official endorsement, either expressed or implied, by the National Aeronautics and Space Administration.

Level of Review: This material has been technically reviewed by technical management.

Available from

NASA Center for Aerospace Information 7115 Standard Drive

Hanover, MD 21076-1320
National Technical Information Service 5301 Shawnee Road Alexandria, VA 22312

Available electronically at http://gltrs.grc.nasa.gov 


\title{
Back-Face Strain for Monitoring Stable Crack Extension in Precracked Flexure Specimens
}

\author{
Jonathan A. Salem and Louis J. Ghosn \\ National Aeronautics and Space Administration \\ Glenn Research Center \\ Cleveland, Ohio 44135
}

\begin{abstract}
Calibrations relating back-face strain to crack length in precracked flexure specimens were developed for different strain gage sizes. The functions were verified via experimental compliance measurements of notched and precracked ceramic beams. Good agreement between the functions and experiments occurred, and fracture toughness was calculated via several operational methods: maximum test load and optically measured precrack length; load at 2 percent crack extension and optical precrack length; maximum load and back-face strain crack length. All the methods gave vary comparable results. The initiation toughness, $K_{I i}$, was also estimated from the initial compliance and load.

The results demonstrate that stability of precracked ceramics specimens tested in four-point flexure is a common occurrence, and that methods such as remotely-monitored load-point displacement are only adequate for detecting stable extension of relatively deep cracks.
\end{abstract}

\subsection{Introduction}

The fracture toughness of ceramics can be measured by a variety of techniques such as the chevronnotched beam (CNB) (Refs. 1 and 2); the single-edge-precracked-beam (SEPB) (Refs. 3 and 4), or the surface-crack in flexure (SCF) (Ref. 5). All of these techniques have been standardized by American Society for Testing and Materials (ASTM) Committee C28.01 as C1421 (Refs. 6 and 7). One issue concerning the techniques is the crack growth stability of the test. This is a fundamental requirement for the chevron-notch technique, and may be required to avoid small errors in the SEPB technique (Ref. 8). The stability of SEPB (Ref. 9) and chevron-notch (Refs. 2 and 10) test specimens has generally been investigated by monitoring load-point displacement (LPD) with the remotely placed, linear variable differential transducer (LVDT) used to control the test system actuator or cross head. Alternatively, stability is presumed or the matter ignored. As the crack extensions in typical ceramic chevron-notched flexure specimens are large $(>0.6 \mathrm{~mm})$, the use of load-point displacement is frequently adequate to detect stability. However, for the SEPB specimen, which is relatively unstable because of the continuously increasing stress intensity factor coefficient, LPD as monitored with a remotely placed LVDT is often inadequate for assessing stability (Ref. 2).

Results presented in this paper demonstrate that stability is the general rule and instability the exception in silicon carbide, silicon nitride, and glass four-point flexure specimens. This brings into question conclusions (Ref. 9) regarding the stability of four-point flexure specimens and the effect on the measured fracture toughness of ceramics. Other work (Ref. 11) also indicates little effect of stability on fracture toughness measured under quasi-static loading conditions.

Another testing issue concerning fracture toughness determination is the measurement of crack length, which has been identified as a major source of error in the fatigue testing of metallic materials (Ref. 12). In ceramic materials, crack length measurement is even more difficult for a number of reasons: the small specimens typically used; the semi-transparent nature of many glass-based ceramics; the lack of plastic deformation at the crack tip which results in poor definition of the crack front; and the high elastic moduli and low fracture toughnesses that results in small crack mouth opening displacements. Coarse grain structure, as in spinels, can also mask the crack front. Although fracture toughness test specimens such as the chevron-notched beam and the double-torsion (Ref. 13) allow the estimation of fracture 
toughness without crack length measurements, they are not always applicable, and other specimens such as the SEPB and the SCF require crack length measurement.

A variety of optical, electrical and mechanical techniques can be used to indirectly or directly measure crack extension in macroscopically cracked specimens. These have been reviewed in detail for application to metallic testing (Ref. 14). For ceramic materials, optical techniques are limited by the small crack opening displacements and the surface finish. Mechanical techniques such as clip gages apply forces to the specimen that can result in significant stress intensities when small test specimens are used.

A simple and sensitive technique that can be used to monitor crack length and extension in both the CNB and SEPB techniques is the back-face strain gage (BFSG). It has been used previously in metallic compact tension specimens (Refs. 14 and 15), and in fracture toughness testing of ceramic flexure specimens (Refs. 16 to 18). Figure 1 shows a strain gage mounted on the back-face of a flexure specimen. Figure 2 shows force as function of LPD and back-face strain (BFS) for a silicon nitride SEPB specimen. Although stable crack extension occurred, as demonstrated by the nonlinear region of the force versus BFS curve just before maximum load, the force versus LPD curve is completely insensitive to the extension. This is a result of remotely placed LVDT's being relatively insensitive to small changes in specimen compliance and therefore unreliable for detecting crack extension in small precracked ceramic specimens.

This paper presents compliance calibration data and new functions for calculating crack length from BFS as measured with different strain gage sizes. The associated errors are determined and recommendations given. Finally, fracture toughness of ceramics and glass is compared for different operational procedures.

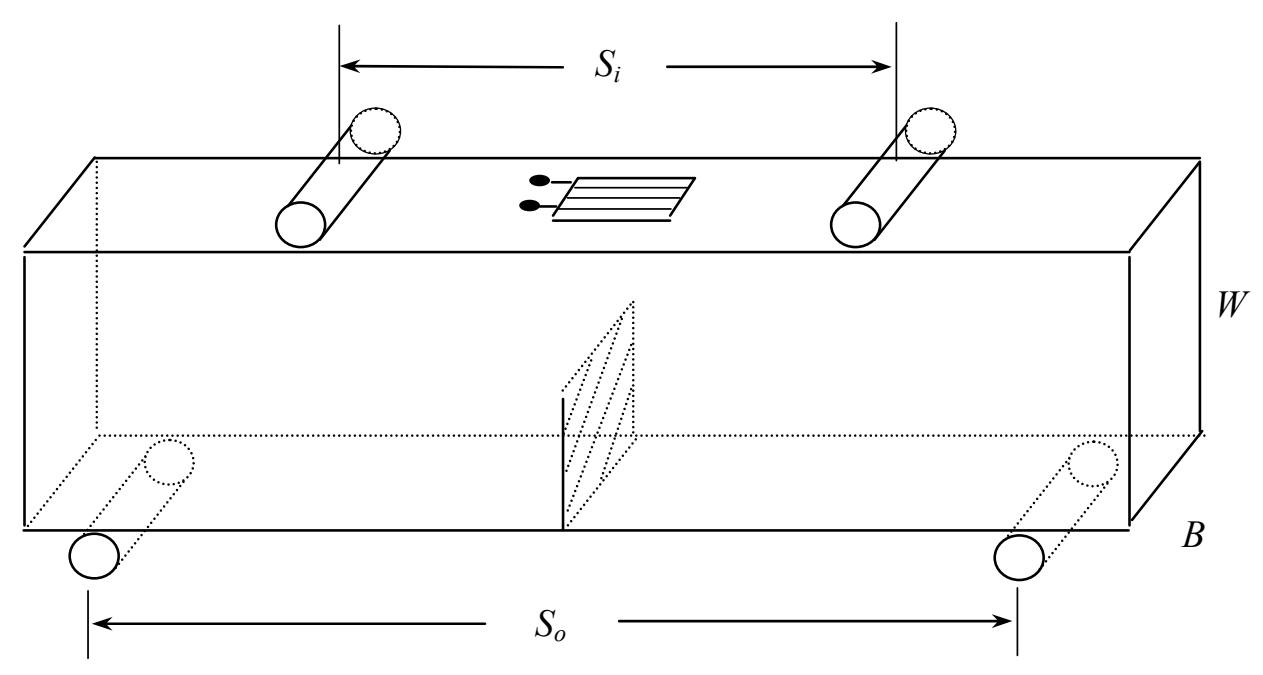

Figure 1.-Strain gage mounted on the back-face of a four-point flexure specimen. 

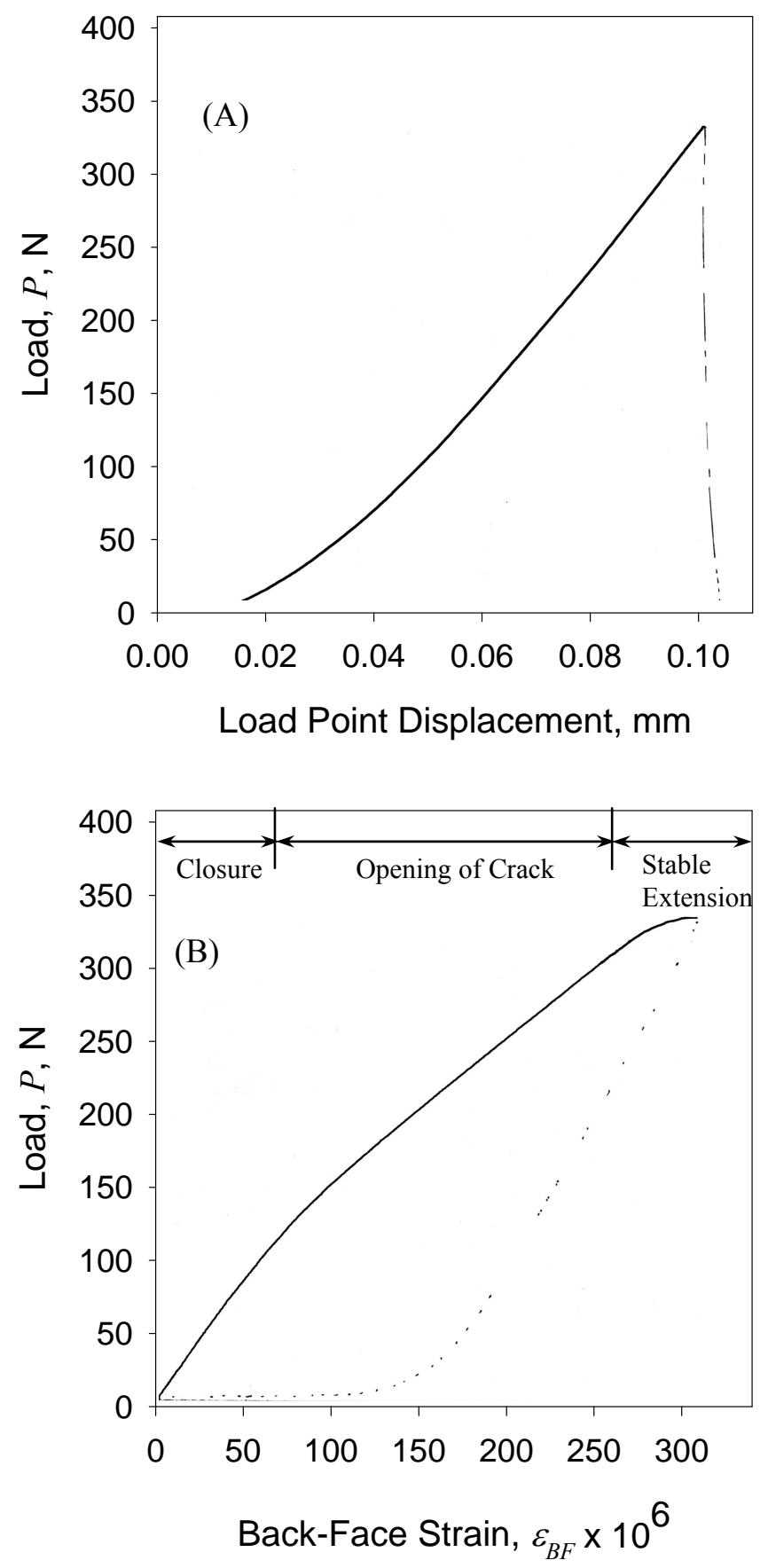

Figure 2.-Load versus load-point-displacement (A) and load versus back-face strain $(B)$ for silicon nitride. 


\subsection{Analysis of Back-Face Strain}

\subsection{Finite Element Analysis}

A two dimensional, plane strain finite element analysis (FEA) was performed to determine the BFS as a function of normalized crack length $(a / W)$ for the four-point flexure specimen. The FEA results from several specimen heights were combined by writing the BFS as

$$
\varepsilon_{B F}=\varepsilon_{N} \frac{P\left(S_{o}-S_{i}\right)}{E B W^{2}}
$$

where $P$ is the applied force, $S_{i}$ and $S_{o}$ are the inner and outer spans, $E$ is the elastic modulus, $B$ is the thickness, $W$ is the height, $a$ is the crack length, and $\varepsilon_{N}$ is the normalized strain taken as a function of normalized crack length. The normalized crack length as a function of absolute normalized BFS as determined from the FEA is shown in Figure 3. For $a / W=0, \varepsilon_{N}=3 / 2$, which correspond to that of an uncracked beam. The BFS is more sensitive to crack length changes for normalized lengths greater than $a / W=0.3$.

The FEA BFS results were fit to

$$
a / W=\frac{A+C \ln \left|\varepsilon_{N}\right|+E\left(\ln \left|\varepsilon_{N}\right|\right)^{2}}{1+B \ln \left|\varepsilon_{N}\right|+D\left(\ln \left|\varepsilon_{N}\right|\right)^{2}+F\left(\ln \left|\varepsilon_{N}\right|\right)^{3}}
$$

where the letters $A$ through $F$ are coefficients listed in Table I. Equation (2) requires $\varepsilon_{N}$ to determine $a / W$. This can be determined from the compliance observed $\left(\varepsilon_{B F} / P\right)$.

TABLE I. -COEFFICIENTS FOR EQUATIONS (2) AND (3) ARE GIVEN FOR THE MAXIMUM (CENTERLINE) STRAIN AND THE AVERAGE STRAIN IN REGIONS ABOUT THE CENTERLINE

\begin{tabular}{|l|c|c|c|c|c|c|}
\hline \multicolumn{7}{|c|}{$a / W=f\left(\left|\varepsilon_{N}\right|\right)$} \\
\hline Region & $A$ & $B$ & $C$ & $D$ & $E$ & $F$ \\
\hline Maximum strain & -0.07481 & -2.13621 & 0.761818 & -0.85086 & -1.42381 & -0.03027 \\
\pm 0.5 mm average & -0.0732199 & -2.1294083 & 0.7643304 & -0.8732785 & -1.4396992 & -0.0197908 \\
\pm 1 mm average & -0.0340202 & -2.2671528 & 0.6392699 & -0.7033830 & -1.3697006 & -0.0253517 \\
\hline \multicolumn{7}{|c|}{$\left|\varepsilon_{N}\right|=f(a / W)$} \\
\hline Region & $A$ & $B$ & $C$ & $D$ & $E$ & $F$ \\
\hline Maximum strain & 1.4953778 & 0.5095193 & -1.1283416 & -3.9701723 & 0.7506841 & 2.4590004 \\
\pm 0.5 mm average & 1.4999604 & 0.4572423 & -1.2038010 & -3.8075832 & 0.8494310 & 2.3526028 \\
\pm 1 mm average & 1.5000003 & 0.0583885 & -1.5493757 & -2.7914306 & 1.2748560 & 1.7382084 \\
\hline
\end{tabular}

For estimation of the normalized back-face strain produced with a given crack length, the results were fit to

$$
\left|\varepsilon_{N}\right|=\frac{A+C(a / W)^{0.5}+E(a / W)}{1+B(a / W)^{0.5}+D(a / W)+F(a / W)^{1.5}}
$$

where the coefficients are listed in Table 1. Equations (2) and (3) provide values within 1 percent for $a / W>0.15$. 


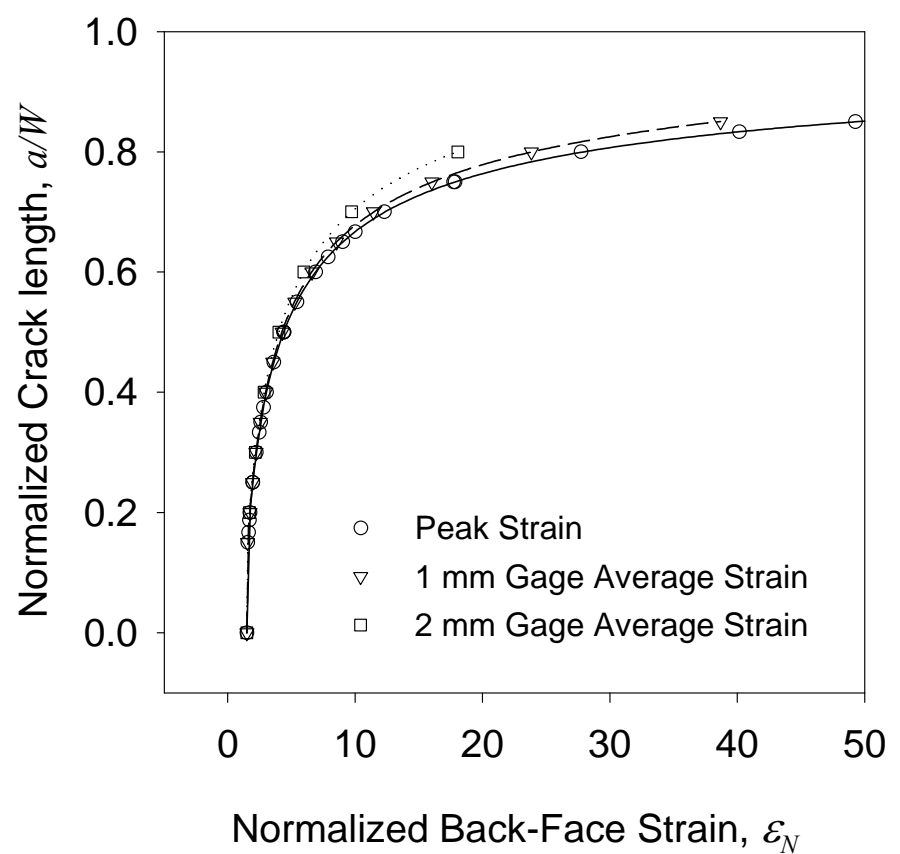

Figure 3.-Normalized crack length as a function of the absolute value of normalized back-face strain.

\subsection{Sensitivity to Specimen Geometry}

The mode I stress intensity function for a beam with a straight through crack loaded in four-point flexure is

$$
K_{I}=\frac{P\left(S_{o}-S_{i}\right)}{B W^{3 / 2}} F(a / W)
$$

where $F(a / W)$ is the stress intensity factor coefficient (Ref. 19). By combining Equations (1) and (4), $\varepsilon_{B F}$ can be written as a function of $1 / \sqrt{ } W$ for a fixed crack length, elastic modulus and stress intensity factor or fracture toughness:

$$
\varepsilon_{B F}=\frac{\varepsilon_{N}}{E} \frac{K_{I}}{F(a / W)} \frac{1}{\sqrt{W}}
$$

Figure 4 shows BFS as a function of normalized crack length for typical properties of silicon nitrides: $E=300 \mathrm{GPa}$ and $K_{I}=5 \mathrm{MPa} \sqrt{\mathrm{m}}$. Reducing the specimen height, $W$, by 50 percent increases the absolute back-face strain by $\sim 40$ percent for $a / W=0.3$. For a constant stress intensity, a minimum in back-face strain occurs around $a / W=0.25$. 


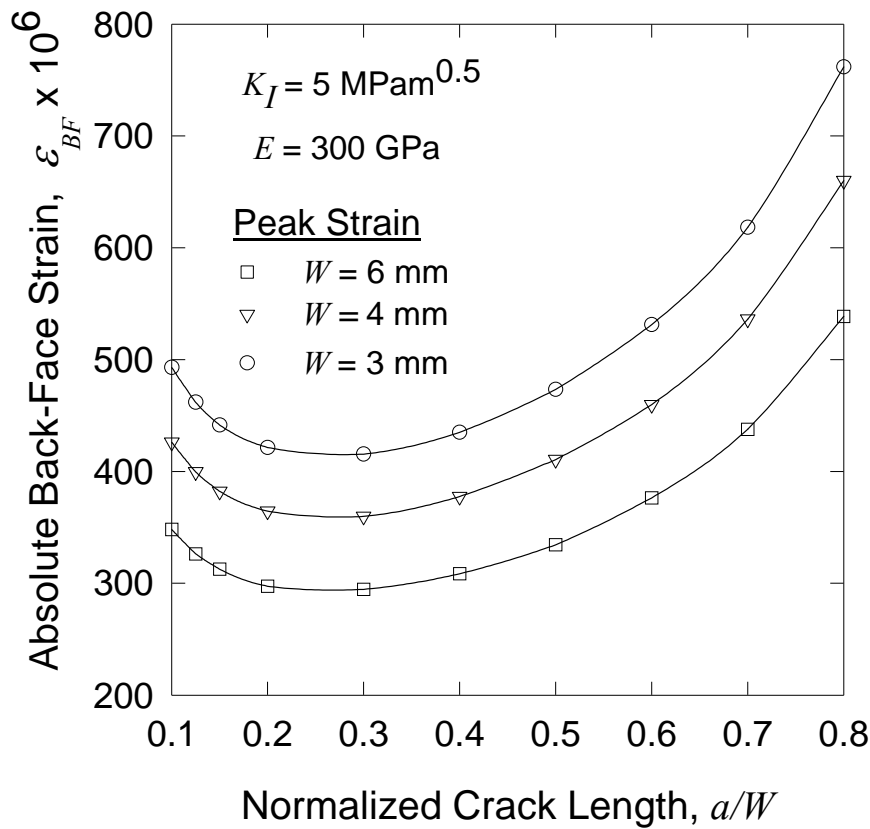

Figure 4.-Absolute back-face strain as a function of normalized crack length for an applied stress intensity factor of $5 \mathrm{MPa} \sqrt{\mathrm{m}}$ and an elastic modulus of $300 \mathrm{GPa}$.

\subsection{Errors Associated With BFS}

\subsection{Uniformity of the Strain Field}

The FEA results were also used to investigate the uniformity of the strain field along the back-face. Figure 5 shows the strain distribution for various normalized crack lengths. For normalized crack lengths less than approximately 0.6 , the strain distribution is relatively uniform over a $\pm 0.5 \mathrm{~mm}$ region about the centerline, corresponding to about 25 percent of $W$. Although strain gages with grid lengths as small as $0.2 \mathrm{~mm}$ are readily available, for deep cracks and larger strain gages, an alternative approach is to derive a BFS calibration from the average FEA strain along a specified length, as done by a strain gage. Table 1 gives coefficients for 1 and $2 \mathrm{~mm}$ gage lengths ( \pm 0.5 and $\pm 1 \mathrm{~mm}$ regions about the specimen centerline).

\subsection{Contact Strains}

Another error associated with the uniformity of the strain field is that due to the contact stresses generated at the loading points. The effect of contact loading on the back-face strain can be estimated from the derivation of von Karman and Seewald (Ref. 20) which is summarized in Reference 21. The contact stress and strain generated in the region between the roller and the crack along the back-face are

$$
\sigma_{x}^{\prime}=\frac{2 \beta P_{c}}{B W} \text { and } \varepsilon_{x}^{\prime}=\frac{2 \beta P_{c}\left(1-v^{2}\right)}{E B W}
$$

where $P_{c}$ is the contact force and $\beta$ is a function of the position and given in Reference 21 . The contact strain as a fraction of the BFS generated solely from the crack presence is

$$
\varepsilon_{x}^{\prime} / \varepsilon_{B F}=\frac{\beta W\left(1-v^{2}\right)}{\varepsilon_{N} S_{i}} .
$$




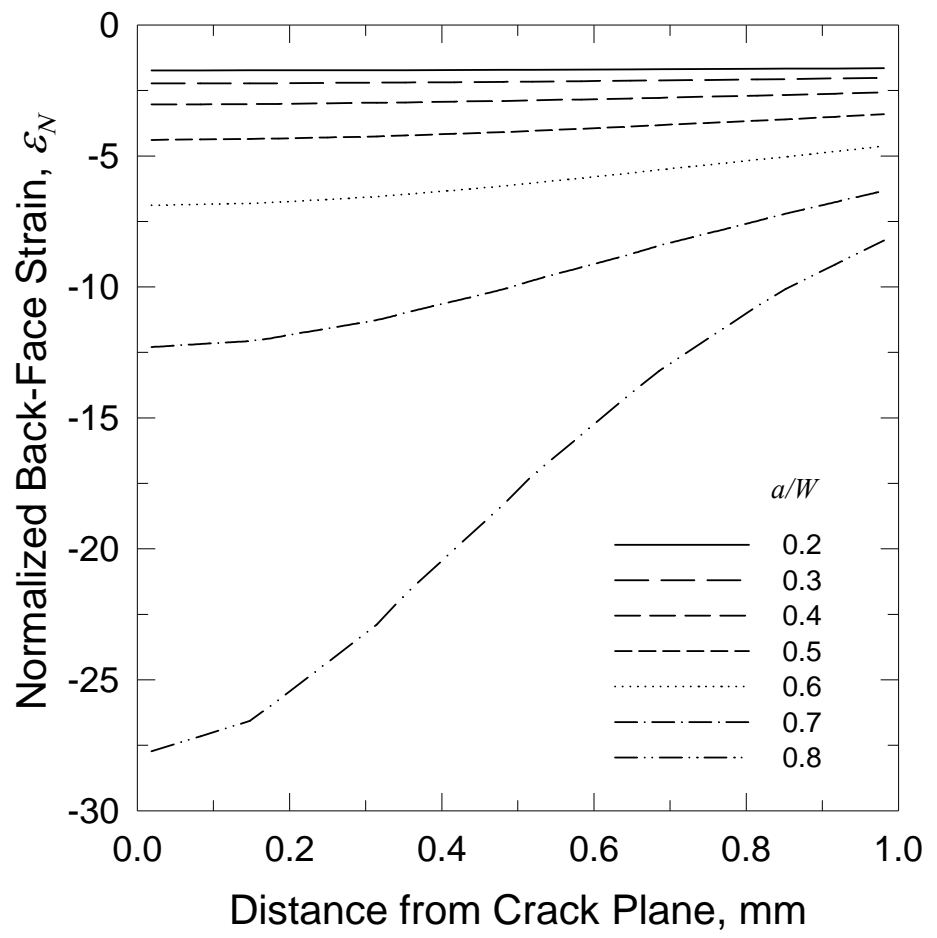

Figure 5.-Variation in strain across the back-face for various normalized crack lengths.

Figure 6 shows the strain ratio as a function of the normalized distance between the crack plane and the roller along the back-face. For normalized crack lengths and span to depth ratios of $a / W \geq 0.3$ and $S_{i} / W \geq 2.5$, the contact strain is less than 1 percent of the back-face strain given by Equation (1) for a $\pm 0.2 S_{i}$ region about the crack plane, or within $\pm 2 \mathrm{~mm}$ for $W=4 \mathrm{~mm}$, implying that the contact strains are very localized and of little consequence for typical gages and spans.

\subsection{Sensitivity to Strain Gage Errors}

The error associated with the estimated crack length as a function of the actual crack length is shown in Figure 7 for $E=300 \mathrm{GPa}, K_{I}=5 \mathrm{MPa} \sqrt{\mathrm{m}}$ and the assumption that a strain gage and conditioner are accurate to \pm 5 microstrain. For normalized crack lengths $\geq 0.3$, the error is less than \pm 2.5 percent for $W \leq 6 \mathrm{~mm}$. The sensitivity of a circuit using a BFSG can be improved by placing multiple gages on the back-face when the specimen size permits, and by using large, high resistance gages. Errors can be minimized by good gage alignment.

\subsection{Experimental Verification}

In order to experimentally verify the FEA BFS calibration, notches were diamond ground into silicon nitride flexure test specimens. Two notch configurations were used to generate BFS data as a function of force: (1) square tip with a $0.76 \mathrm{~mm}$ long uniform section preceded by a $0.76 \mathrm{~mm}$ long, $60^{\circ}$ mouth, and (2) a V-grooved tip (Ref. 22) preceded by $0.76 \mathrm{~mm}$ straight and $60^{\circ}$ sections, shown in Figure 8 . The notches had an average width of $0.18 \mathrm{~mm}$ in the uniform section and the $\mathrm{V}$-grooves had an average radius of $0.036 \mathrm{~mm}$. Although such notches are too blunt for fracture toughness measurements, they were thought adequate for compliance measurements. The specimens were loaded between 20 and $40 \mathrm{~mm}$ spans at a rate of $20 \mathrm{~N} / \mathrm{s}$. 


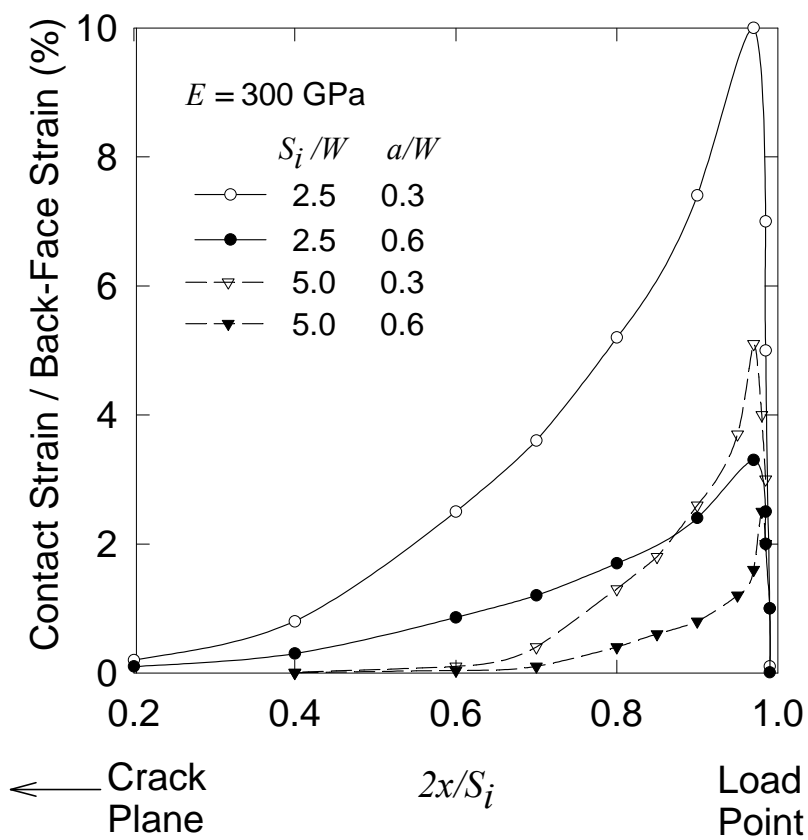

Figure 6.-Contact strain normalized to back-face strain as a function of normalized distance from the load-point.

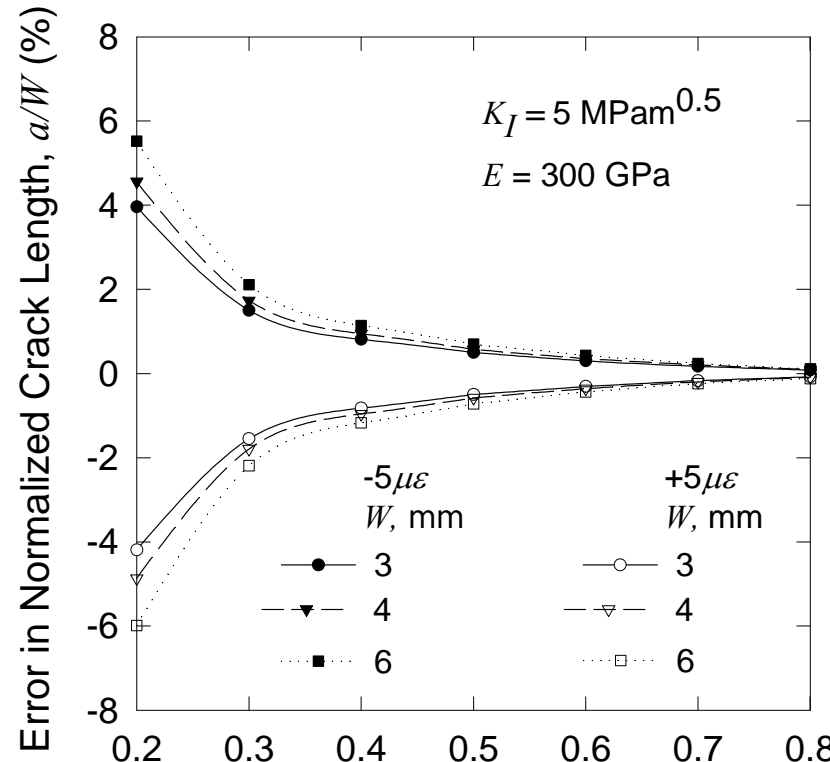

Normalized Crack Length, $a / W$

Figure 7.-Error in estimated crack length for a gage accuracy of \pm 5 microstrain with an applied stress intensity factor of 5 $\mathrm{MPa} \sqrt{\mathrm{m}}$ and an elastic modulus of $300 \mathrm{GPa}$. 


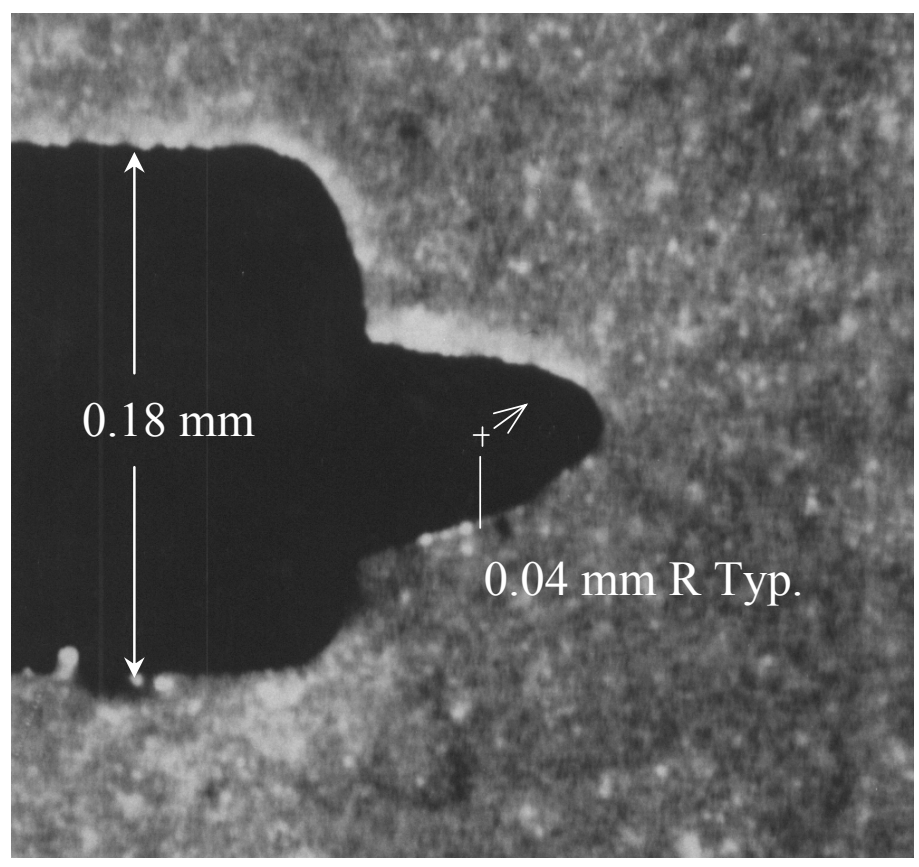

Figure 8.-Notch configuration used to verify FEA.

The resulting, normalized crack lengths predicted from the slope of the force versus BFS curves and Equations (1) and (2) are plotted as a function of the optically measured, normalized notch depth, $l / W$, in Figure 9. Overall agreement was good for $a / W \geq 0.4$, with a maximum error of 2.9 percent for the square notched specimens and 0.2 percent for the V-notched specimens. However, for shorter $a / W$ the BFS data tended to overestimate the notch length, and a slight bias in the data is apparent as the BFS estimated lengths are usually longer than the optically measured values by an average of $0.035 \mathrm{~mm}$ for the square notches and $0.012 \mathrm{~mm}$ for the $\mathrm{V}$-notches. In order to determine if this was an artifact of the relatively blunt notch or machining cracks at the notch root, specimens were heat treated (Ref. 23) and the notch modeled with FEA. Annealing did not improve the results; however, modeling of the notch root shape produced good correlation between analysis and experiments.

Three of the saw-notched specimens made from the GPS silicon nitride were loaded to failure at $0.5 \mathrm{~mm} / \mathrm{min}$. No non-linear behavior was exhibited prior to catastrophic failure, indicating good bonding of the strain gages and no stable crack extension for the notched specimens.

\subsection{Experiments With Sharp Cracks}

\subsection{Materials}

The test materials (Table II) were a hot isostatically pressed (HIPed) silicon nitride ${ }^{1}$ exhibiting a flat crack growth resistance curve (R-curve) (Ref. 24), a hot pressed (HP) in situ toughened silicon nitride ${ }^{2}$

${ }^{1}$ GN 10, Allied Signal Ceramic Components, Torrance, California.

${ }^{2}$ NKK Corp., Tokyo, Japan 
exhibiting a rising R-curve (Ref. 25), a gas pressure sintered (GPS) in situ toughened silicon nitride ${ }^{3}$ exhibiting a rising R-curve (Ref. 26), a composite silicon nitride ${ }^{4}$ with 20 vol. \% SiC whiskers, sintered silicon carbide ${ }^{5}$, and soda-lime glass.

TABLE II.-PROPERTIES OF THE TEST MATERIALS

\begin{tabular}{|l|c|c|c|}
\hline \multicolumn{1}{|c|}{ Material } & $\begin{array}{c}\text { Elastic }^{\mathrm{A}} \text { modulus } \\
\mathrm{GPa}\end{array}$ & $\begin{array}{c}\text { Hardness } \\
\mathrm{GPa}\end{array}$ & $\begin{array}{c}\text { Number of } \\
\text { fracture tests }\end{array}$ \\
\hline Soda Lime Glass & 70.6 & $6.3 \pm 0.5$ & 4 \\
Alpha Silicon Carbide & 397 & -- & 5 \\
HIPed Silicon Nitride (GN-10) & 285 & $14.4 \pm 0.1$ & 6 \\
Composite Silicon Nitride/20\% SiC & 298 & 17.4 & 3 \\
GPS Silicon Nitride (AS-800) & 299 & $14.3 \pm 0.7$ & 5 \\
HP Silicon Nitride (NKK) & 298 & $14.5 \pm 0.2$ & 4 \\
\hline
\end{tabular}

A. By strain gaging a four-point flexure specimen.

B. With a Vickers microhardness indentor.

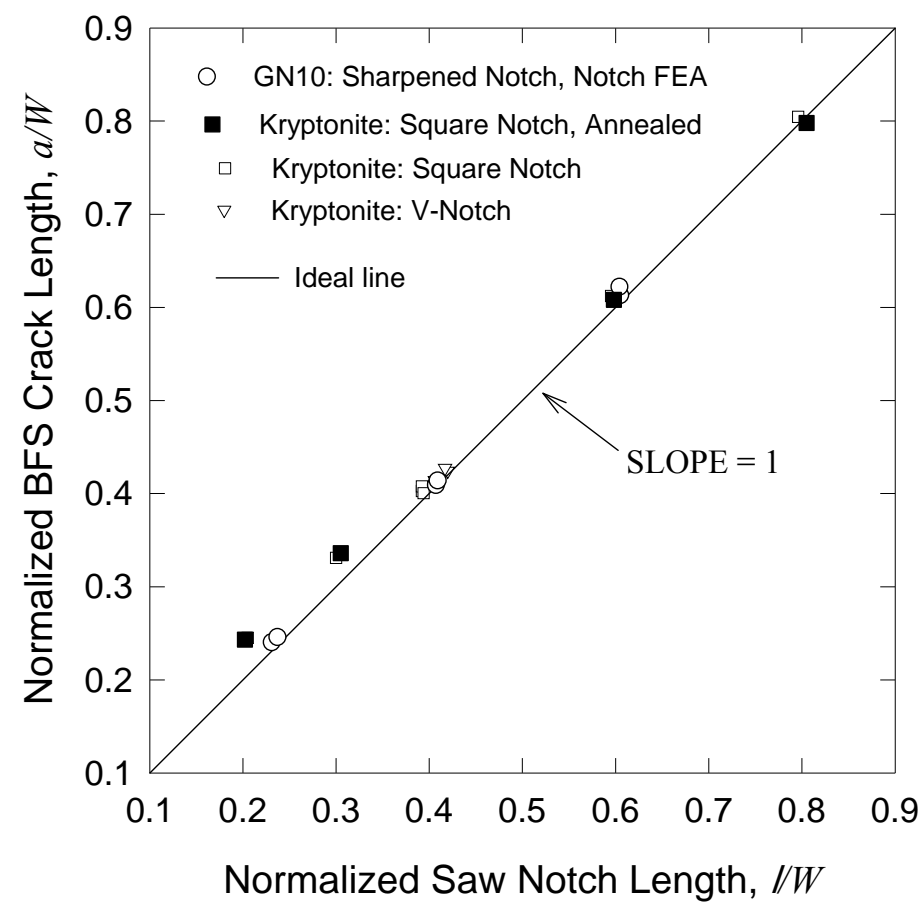

Figure 9.-Normalized notch length determined from optical measurements and back-face strain measurements.

${ }^{3}$ AS-800, Allied-Signal Ceramic Components, Torrance, California.

${ }^{4}$ Kryptonite, Japan Metals and Chemicals Co., Tokyo, Japan.

${ }^{5}$ Hexoloy SA Sintered alpha $\alpha$-SiC, St. Gobain (Carborundum), Niagara Falls, New York. 


\section{$5.2 \quad$ Test Geometries}

The HIPed and HP silicon nitride specimens measured 3 by $6 \mathrm{~mm}$ and 3 by $4 \mathrm{~mm}$ in thickness and height, respectively, and were tested between 10 and $20 \mathrm{~mm}$ spans at a rate of $0.05 \mathrm{~mm} / \mathrm{min}$. The GPS and composite silicon nitride specimens measured 3 by $4 \mathrm{~mm}$ in thickness and height, and were tested between 20 and $40 \mathrm{~mm}$ spans at a rate of $0.5 \mathrm{~mm} / \mathrm{min}$. The silicon carbide specimens measured 3 by 4 $\mathrm{mm}$ in thickness and height, and were tested between 10 and $20 \mathrm{~mm}$ spans at a rate $0.01 \mathrm{~mm} / \mathrm{min}$. The glass specimens measured 5 by $8 \mathrm{~mm}$ in thickness and height and were tested between 20 and $40 \mathrm{~mm}$ spans at a rate of $0.5 \mathrm{~mm} / \mathrm{min}$. Test system stiffness ranged from 3,000 to $10,000 \mathrm{~N} / \mathrm{mm}$.

\subsection{Precracking and Loading Mode}

The specimens were precracked using the bridge indentation technique (Refs. 3 and 4). After precracking, a uniaxial strain gage (typically less than $1 \mathrm{~mm}$ gage length) was centered on the back-face opposite the precrack mouth. The precrack was then marked by applying a drop of oil based dye penetrant ${ }^{6}$ as described in the next section.

Specimens were loaded with one of the following modes: monotonic loading in displacement control until final fracture occurred, or monotonic loading until an increment of crack extension occurred, followed by unloading and reloading until another increment of crack extension occurred. This cycle was repeated several times until catastrophic failure. After failure, the crack length, as indicated by the dye penetrant, was immediately measured in an optical microscope at approximately $30 x$ magnification. The specimens were then washed with acetone and the physical crack lengths optically measured.

\subsection{Crack Marking}

The precracks were marked by applying a drop of dye penetrant ${ }^{6}$ to the crack mouth and allowing it to penetrate for a minimum of several minutes. Prior to testing, excess penetrant was swabbed from the surfaces with cotton and a solvent.

Penetrants are designed to infiltrate the crack and be wiped from the surface while retaining the ability to bleed out of a defect upon application of a developer. As a result, they tend to remain fluid and to creep or spread in the presence of a developer, making them a less than ideal agent for marking the length of a crack that is to be broken open. Thus, any crack length measurements must be made immediately after specimen failure and viewed with some suspicion. The tendency of a penetrant to spread away from the defect can be reduced by thinning with solvent (Ref. 27).

Cracks in ceramics are very narrow and the degree of penetration is an issue. Studies on glass slide plates indicate that most penetrants and water will fill gaps less than $0.3 \mu \mathrm{m}$ (estimates are as low as $0.1 \mu \mathrm{m}$ ) (Ref. 27). The results presented in the results section indicate that penetration is typically sufficient.

Ideally, a penetrant that will penetrate very tight cracks, dry without adhering the crack faces, and leave an indication is needed. The penetrant used in this study can be dried by baking in an oven at about $160{ }^{\circ} \mathrm{C}$, however, a sticky residue that bonds the crack faces together results. If higher temperatures are used, the residue is hardly visible. An alternative is to use a lead acetate solution and a wetting agent. The disadvantage is that the dried lead acetate is not readily visible with optical methods, and thus scanning electron microscopy with back scattered electron imaging is required.

\subsection{Corrosive Effects of Penetrants}

The fatigue crack growth rates and threshold stress intensity factors of ceramics and glasses are affected by moist or humid environments. Thus, any penetrant used to mark the crack may enhance or retard such stress corrosion crack growth and thereby affect the properties being measured. Many

\footnotetext{
${ }^{6}$ DP-40, Sherwin Inc., South Gate, California.
} 
penetrants, though oil based, contains emulsifiers that may form an alkaline solution if water gets into the container (Ref. 27). Such a water based alkaline solution could enhance corrosion of glasses and some ceramics.

The corrosive properties of the penetrant used in this study were investigated by running constant stress rate tests on glass specimens that were precracked by using a Vickers indenter with a $49 \mathrm{~N}$ load. After indenting, the specimens were dried for various times by placing them in a desiccator attached to a vacuum pump. The specimens were then removed, marked with the penetrant or silicon oil, and loaded at displacement rates that resulted in stressing rates from 10 to $1000 \mathrm{MPa} / \mathrm{min}$.

The resulting failure strengths are plotted in Figure 10. For specimens that are sufficiently dried $(\geq 3.5$ hr), the silicon oil (which acts as an inert environment) and the penetrant result in similar strengths and a large crack growth parameter $(n=80)$. However, for specimens dried less than $3.5 \mathrm{hr}$, a loss in strength (18 percent) and a crack growth parameter typical of glass $(n=22)$ is exhibited. This result is in agreement with crack growth parameters measured statically and dynamically with indentation flaws in water ( $n=18$ to 22 (Refs. 28 and 29)), indicating that the penetrant does not affect slow crack growth behavior unless significant vacuum drying is performed.

\subsection{Results}

\subsection{Capabilities of Penetrant}

Figure 11 shows crack lengths determined from the same specimens with penetrant and after washing the penetrant off. Agreement was excellent except when the crack front could not be readily delineated and measured at three points along the crack front: the mid-thickness and the two quarter-thickness points. Such results are plotted with zero values on the abscissa. Measurements without penetrant were particularly difficult for the in situ toughened materials because of the coarse microstructure.

It was noted during the optical precrack measurements that when the precrack segment and the fast fracture segment were well aligned, the crack could not be detected optically without using penetrant, as shown in Figure 12(A) and (B). This occurred in about 25 percent of the specimens. For such specimens, the crack length as measured with the penetrant was used for any further calculations requiring a crack length.

Evidently, optical measurements without penetrant detect the line of intersection formed by the precrack and fracture planes, as shown in Figure 12(C) and (D). The misalignment is the result of the precrack tip turning out of plane or being "hooked."

The specimen showing the worst agreement was a HIPed silicon nitride specimen cycled multiple times before failure occurred. The BFS indicated crack growth of $0.34 \mathrm{~mm}$ prior to failure, corresponding to three-quarters of the discrepancy shown in Figure 11. Evidently the penetrant, to a large extent, follows the crack when it is extended by cycling.

Crack lengths determined without penetrant measure the initial, physical length of a crack that is frequently out of plane with the final fracture plane. Thus both the optical and penetrant measurements are good approximations of the initial, physical crack length for monotonic loading if little crack extension occurs. However, the penetrant provides a better, though possibly inadequate estimate of the final, physical crack length when the crack is cycled.

\subsection{Crack Length Estimation From BFS}

Silicon nitride specimens exhibited three distinct regions: a short steep region; a large semi-linear region; and a short, highly nonlinear region (Fig. 2). Glass specimens exhibited only the second two regions and the saw notched specimens exhibited only a single linear region.

The initial region represents the effective stress intensity factor or load to begin opening the precrack and overcome the "closure" caused by wedging of grains and asperities in the precrack wake. The middle region represents the compliance of the precrack and its slope was used to estimate the precrack lengths. The third region represents stable crack extension. 


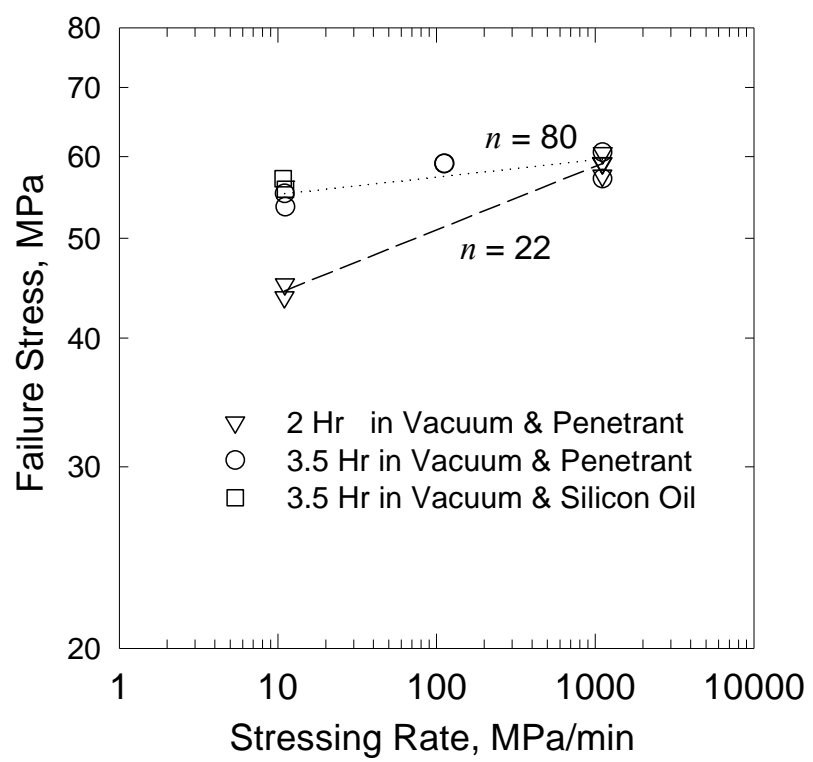

Figure 10.-Fatigue strength of glass slide plates subjected to vacuum drying and marking with penetrant or silicon oil.

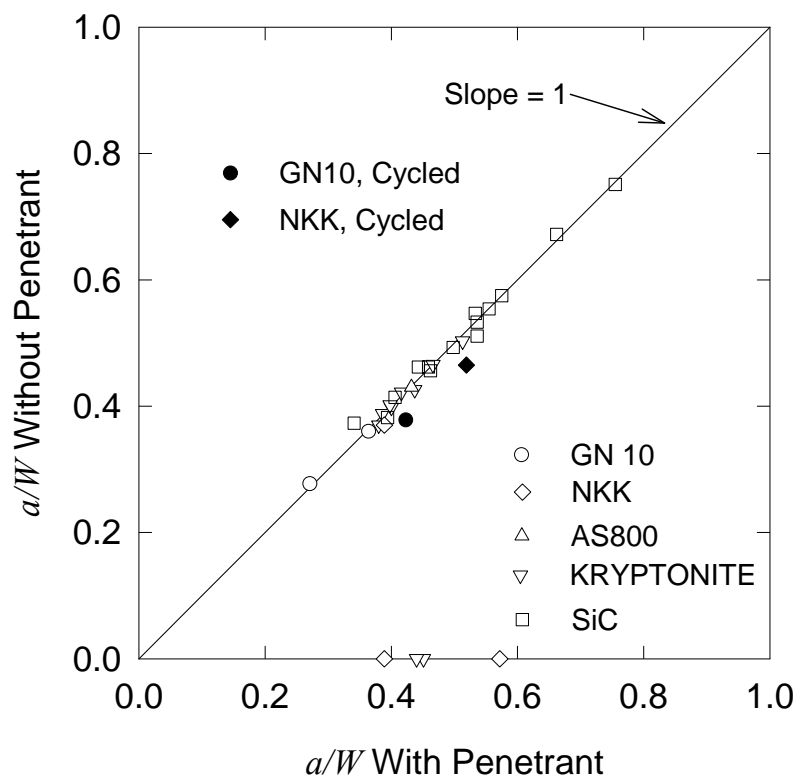

Figure 11.-Normalized crack length measured with and without penetrant. 

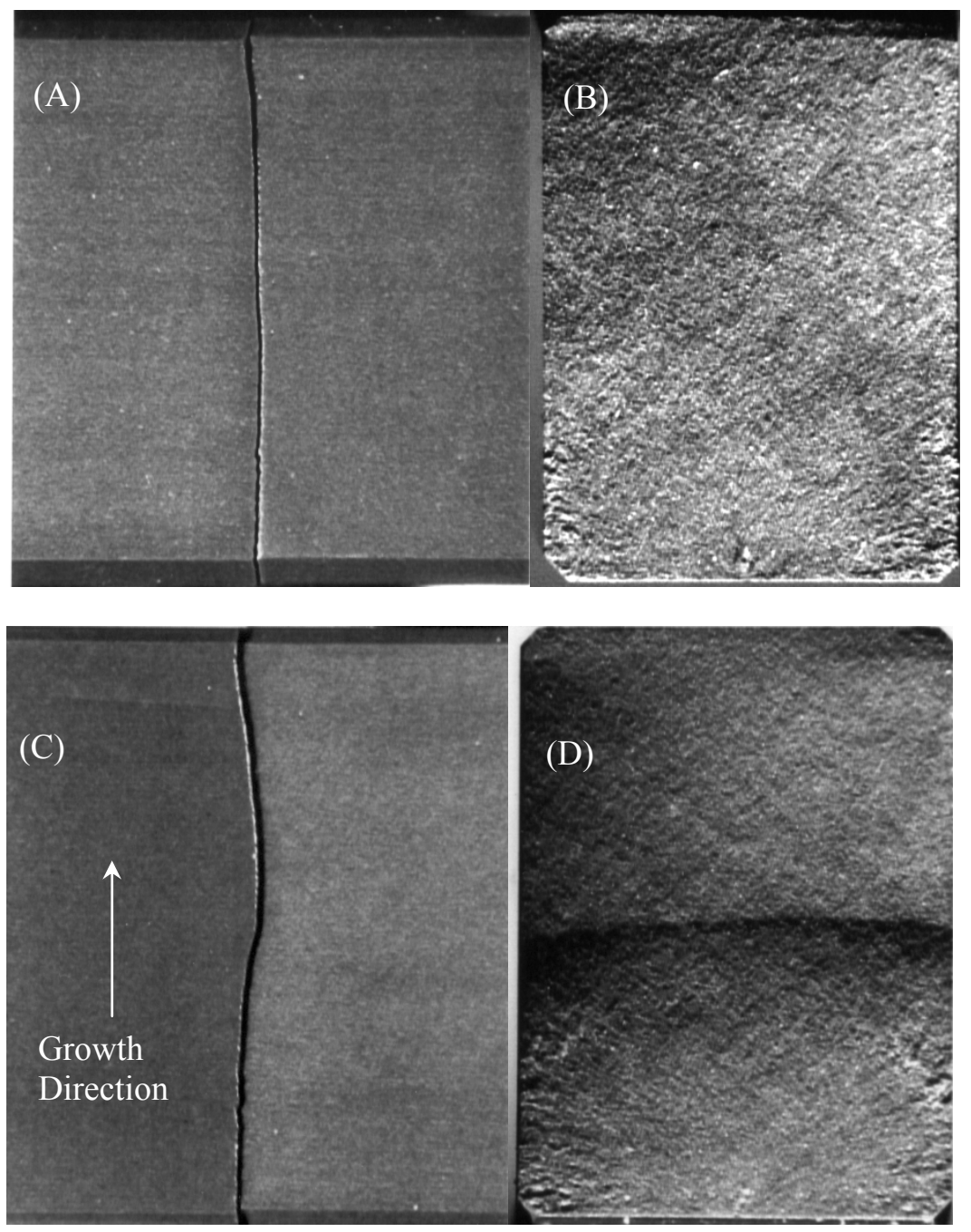

Figure 12.-Effect of precrack shape on optical visibility: (A) and (B) are side and top views of a coplanar precrack and failure plane; (C) and (D) are views of a precrack with a curved tip.

Figure 13 compares the precrack length measured optically (generally without penetrant) with estimates made from the slope of the second region in the load-BFS curves. Excellent agreement is indicated for the HIPed material, which has a fine grain size, and the glass, which is amorphous. For the coarse grained, in situ toughened materials, the BFS slightly underestimates the optically measured precrack length. This is probably due to grain bridging in the crack wake that results in crack growth resistance and the appearance of a shorter crack.

In order to determine final compliance and the amount of stable crack extension occurring in the tests, a compliance line was drawn on the load-BFS curve from the final fracture point to the zero load point of the initial compliance line. Figure 14 compares the precrack length measured optically with estimates made from the load-BFS curves. All but two SiC test specimens exhibited measurable crack extension. On average, the silicon nitride materials extended 5 percent while the $\mathrm{SiC}$ extended 2.3 percent.

Specimens subjected to several load-unload cycles exhibited substantial stable crack extension $(>0.20$ $\mathrm{mm}$ ), and the corresponding crack growth resistance curves based on BFS from a single specimen are shown in Figure 15. 


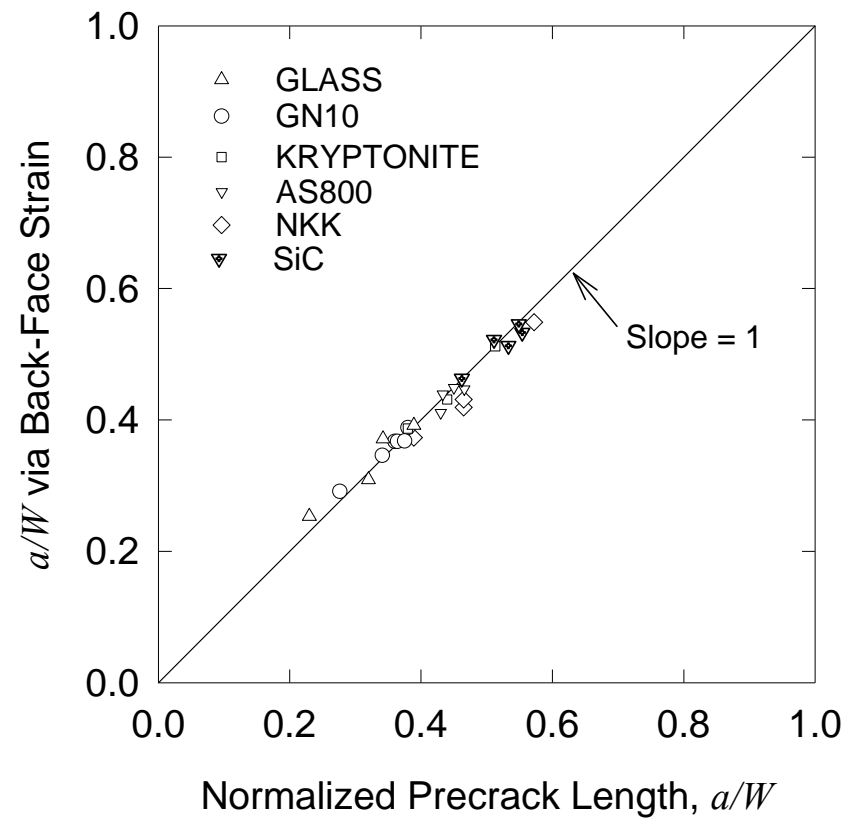

Figure 13.-Comparison of precrack lengths determined by optical measurements and by the initial compliance as measured with back-face strain.

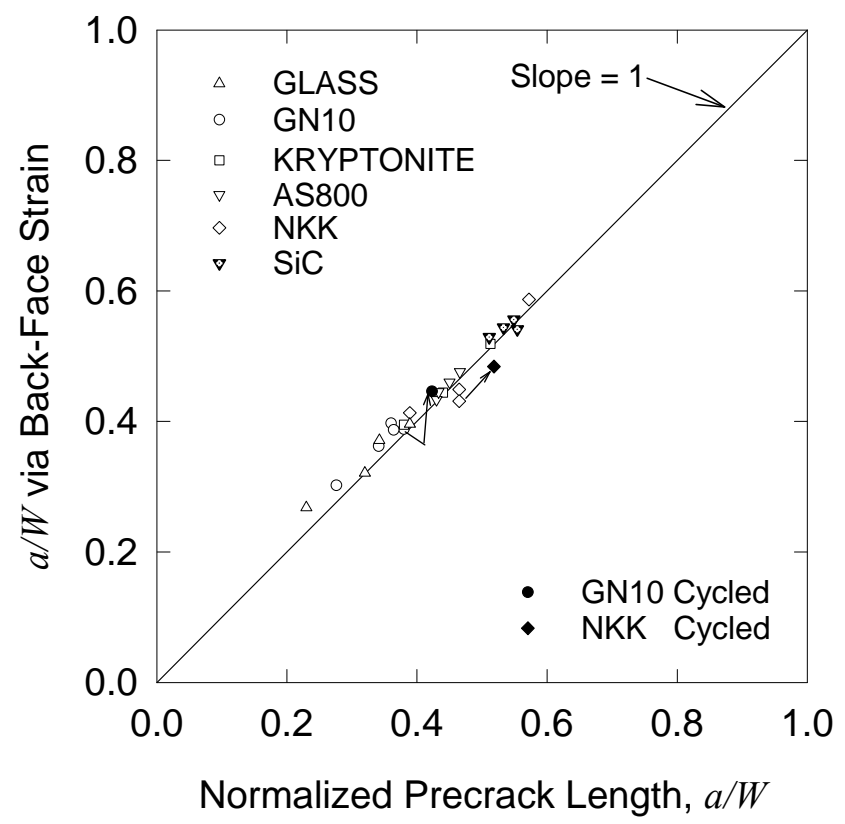

Figure 14.-Comparison of precrack lengths determined by optical measurements and by the final compliance as measured with back-face strain. Arrows show extension due to cycling. 


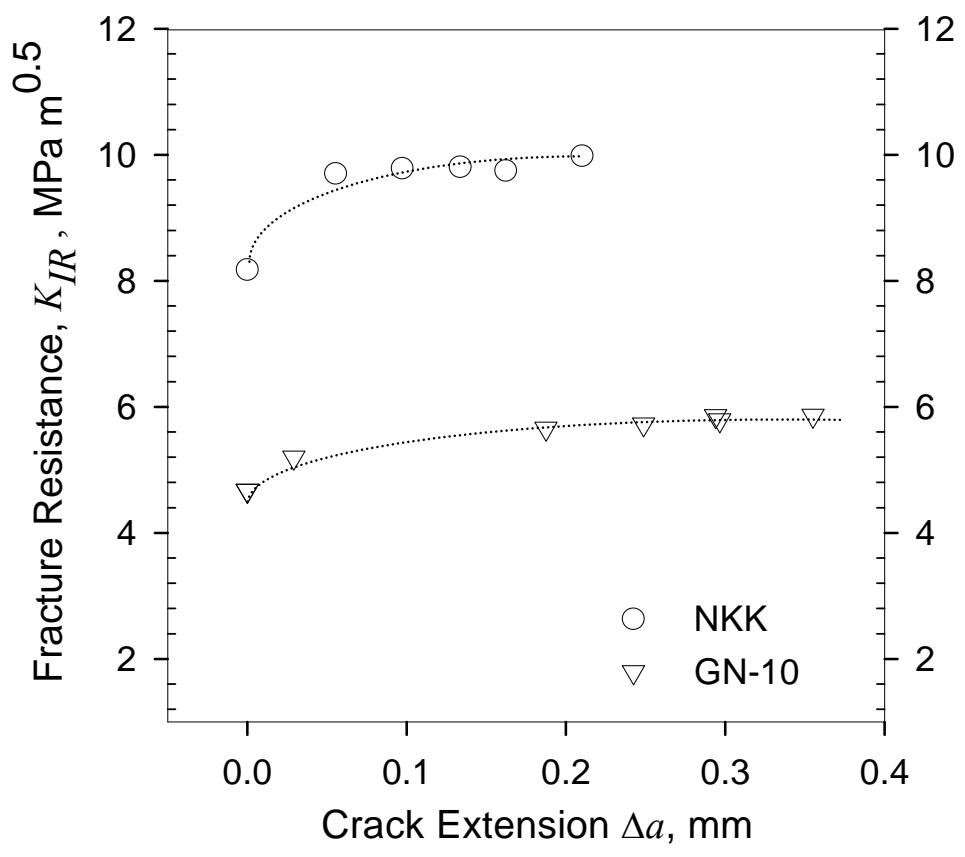

Figure 15.-Crack growth resistance curves determined from BFS measurements.

\subsection{Fracture Toughness Estimation}

Fracture toughness can be calculated by a variety of methods: from the maximum load and optically measured precrack length; from the load at the onset of crack extension and the corresponding precrack length as measured with BFS; or from the maximum load and the corresponding crack length as estimated with BFS. Typically the first of these techniques has been used (Refs. 6 and 7) for very brittle failure in which little or no crack extension occurs. The second technique is complicated because the onset of crack extension and associated load are difficult to identify. However, this complication can be avoided by applying the technique used in ASTM E399 (Ref. 30). A slope that corresponds to a fixed crack extension (e.g., $\sim 2$ percent) is drawn on the loading diagram and the load corresponding to the intersection used to calculate the fracture toughness. Values calculated by various methods are listed in Table III, and the first and second methods are plotted in Figure 16. Only data from monotonically loaded specimens were used. Fracture toughnesses calculated with the maximum load and optical precrack length agree reasonably with those calculated from the load for 2 percent crack extension, $P_{Q}$, and the optical precrack length. This occurs because the crack extension is small and occurs under nearly constant load.

TABLE III.-STRESS INTENSITY FACTORS (MPa $\sqrt{M})$ CALCULATED WITH VARIOUS OPERATIONAL METHODS

\begin{tabular}{|l|c|c|c|c|c|}
\hline & $K_{I p b}$ & $K_{I Q}$ & $K_{I B F S}$ & $K_{I i}$ & $K_{I R}$ \\
\hline \multicolumn{1}{|c|}{ Load } & Maximum & $P_{Q}$ & Maximum & Initiation & Final \\
\hline Crack length & Optical precrack & Optical precrack & BFS precrack & BFS precrack & BFS final crack \\
\hline Glass & $0.70 \pm 0.01$ & $0.70 \pm 0.01$ & $0.71 \pm 0.03$ & $0.61 \pm 0.03$ & $0.72 \pm 0.04$ \\
Alpha SiC & $2.59 \pm 0.15$ & $2.57 \pm 0.19$ & $2.53 \pm 0.10$ & $2.40 \pm 0.11$ & $2.53 \pm 0.10$ \\
$\mathrm{HIPed} \mathrm{Si} \mathrm{N}_{4}$ & $5.42 \pm 0.17$ & $5.38 \pm 0.20$ & $5.53 \pm 0.19$ & $5.20 \pm 0.15$ & $5.81 \pm 0.11$ \\
$\mathrm{Si}_{3} \mathrm{~N}_{4} / \mathrm{SiC}^{\mathrm{GPS} \mathrm{Si}} \mathrm{N}_{4}$ & $6.62 \pm 0.17$ & $6.56 \pm 0.16$ & $6.53 \pm 0.10$ & $5.92 \pm 0.33$ & $6.54 \pm 0.10$ \\
$\mathrm{HP} \mathrm{Si}_{3} \mathrm{~N}_{4}$ & $7.68 \pm 0.15$ & $7.52 \pm 0.19$ & $7.58 \pm 0.35$ & $7.18 \pm 0.40$ & $7.91 \pm 0.13$ \\
\end{tabular}




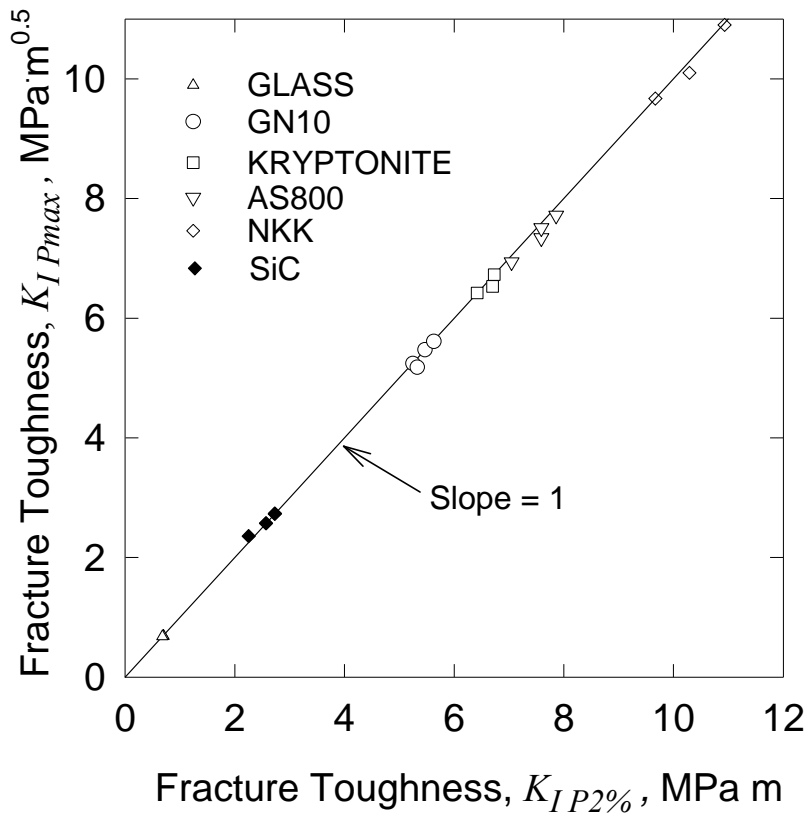

Figure 16.-Comparison of the fracture toughnesses determined with maximum load and the load for 2 percent crack extension.

\subsection{Effects of Crack Configuration on Stable Extension}

SEPB precracks exhibit varying degrees of crack front straightness, and the cracks frequently curve out of the initial crack plane near the crack tip. The amount of stable crack extension exhibited in ceramics may be related not only to the materials crack growth resistance and sensitivity to stress corrosion, but also to the degree of crack tip hook and crack front straightness.

The effect of crack front straightness on the degree of crack extension is shown in Figure 17. No particular trend is exhibited. The straightness was defined as the maximum of the differences between the crack lengths measured at the center and the two mid-centers of the specimen thickness.

The effect of precrack length on the stable crack extension is shown in Figure 18. Again, no trend can be discerned.

The effect of out-of-plane curvature on the fracture toughness of the composite material, as calculated with the maximum load and optically measured crack length, is shown in Figure 19. No significant effect is exhibited. The hook angle was defined as the angle between lines drawn tangent to the initial crack plane and the crack tip.

As mentioned in the previous section, two SiC test specimens did not exhibit stable extension, but crack jumps followed by unstable failure. The cracks in these specimens were noted to be relatively twisted, with fracture toughness of 2.73 as compared to $2.59 \mathrm{MPa} \sqrt{\mathrm{m}}$ for ideal cracks.

A more systematic study with a wider parameter range may be needed to distinguish the factors controlling the amount of stable extension. 


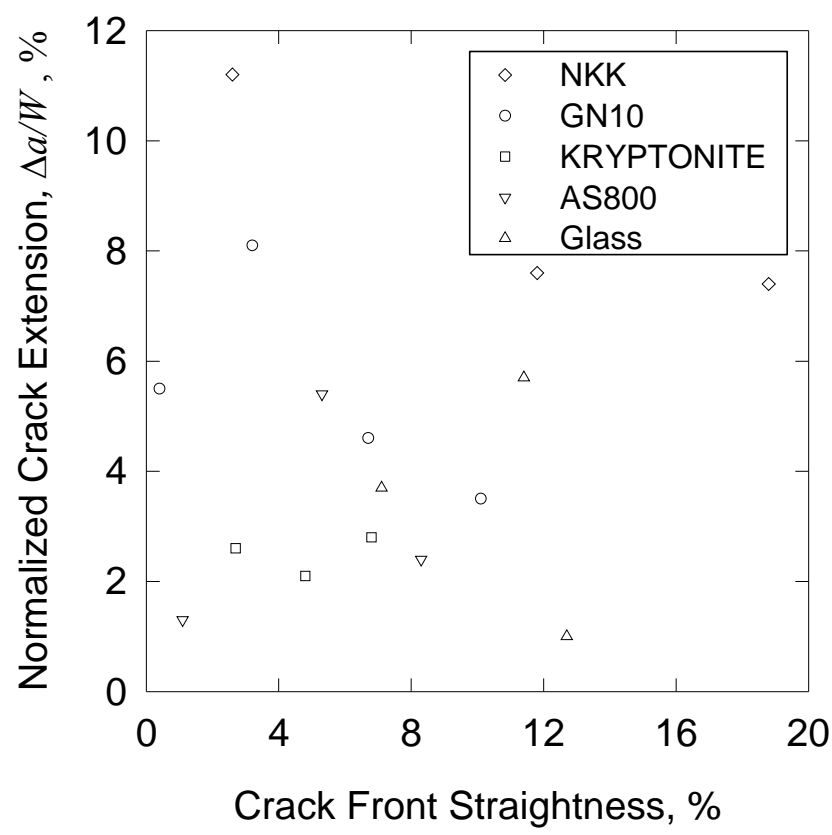

Figure 17.-Normalized crack extension as a function of crack front straightness.

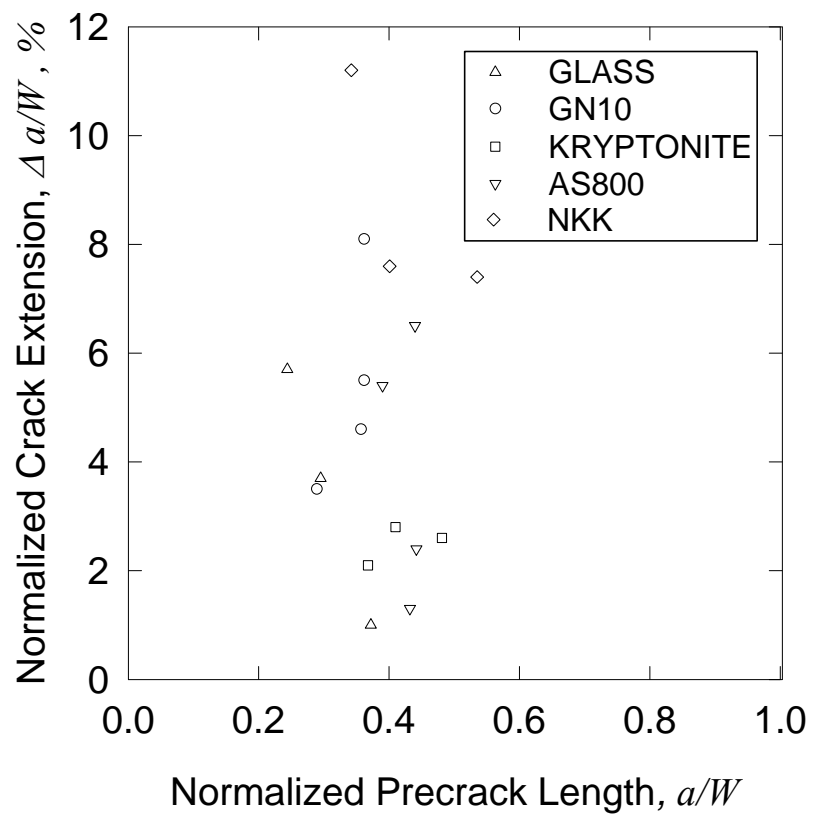

Figure 18.-Normalized crack extension as a function of normalized precrack length. 


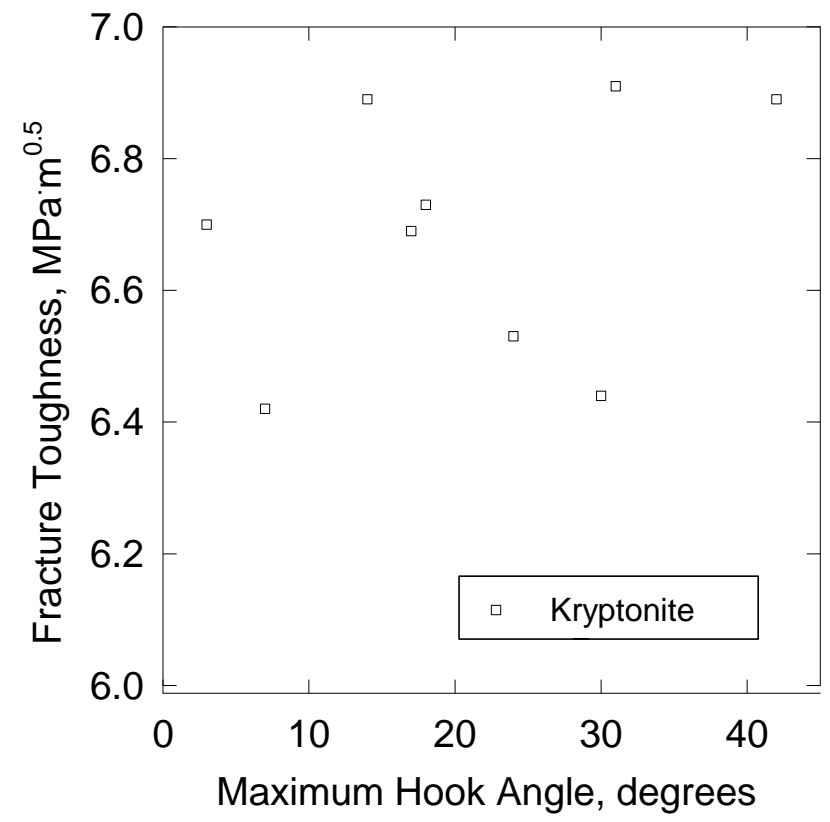

Figure 19.-Fracture toughness as function of crack hook angle.

\subsection{Discussion}

Most noteworthy of the results is that crack stability during fracture of ceramics is the rule rather than the exception, regardless of the test material or crack length. However, adequate detection techniques must be used as demonstrated by Figure 2, otherwise stable tests may be interpreted as unstable. Further, use of a very large load cell in order to promote system stiffness and stability, as done in Reference 9, is ill advised as the precision is diminished. The tests in this work used 500 to $2000 \mathrm{~N}$ load cells.

The apparent lack of stability reported in Reference 9 is the result of using a remotely placed LVDT to detect compliance changes. For long cracks the compliance and its change are large and can marginally be detected; however, for short cracks, the changes are too small for detection via the LVDT.

The lower fracture toughness observed in Reference 9 for specimens that had long cracks and appeared to be stable is probably a result of the crack extension changing the actual SIFC (stress intensity factor coefficient) in long cracks more than for short cracks, and the use of the SIFC corresponding to the precrack. For long cracks the SIFC increases more rapidly than for short cracks. Thus for any crack extension the error between the real SIFC and that associated with the precrack length is exacerbated as the crack length becomes greater. Another other source of error associated with crack stability is that resulting from poor crack configuration. For example, twisted cracks exhibit little or no stable crack extension. The instability probably results from the divergent paths along the crack front causing pinning so that a larger load, which is usually unstable, is required for propagation. This led to larger apparent fracture toughness measurements in Reference 2.

Fracture toughness measurements made with maximum load and the precrack length are comparable to those made with 2 percent extension for the materials tested. Initiation stress intensities and maximum resistive intensities are significantly different. Crack closure was exhibited by the materials with coarse microstructures, and thus the initiation toughness values are likely higher than the initiation toughness associated with a traction-free crack or possibly a fatigue crack. Fatiguing of precracked specimens or use of the SEVNB specimen may provide better measurements of initiation values. 


\subsection{Summary}

The back-face strain gage is a simple, inexpensive method for monitoring crack extension in ceramic flexure specimens during fracture toughness testing, and indicates that four-point flexure is adequately stable for accurate fracture testing of ceramics. It is recommended that the crack length be between $0.3 \leq a / W \leq 0.6$ with $1 \leq W / B \leq 2$ and $\mathrm{S}_{\mathrm{i}} / \mathrm{W} \geq 2.5$. For small flexure specimen, strain gages should have a gage length less $1 \mathrm{~mm}$.

All silicon nitride specimens tested exhibited stable extension prior to fast fracture, despite the use of four-point flexure. Unstable extension occurred only for two silicon carbide specimens that contained twisted cracks. An average stable crack extension of 5 percent, as measured with the BFSG, occurred in the silicon nitrides tested. For silicon carbide an average extension of 2.3 percent occurred. Precrack lengths are difficult to optically measure when the precrack plane and the final fracture plane are well aligned. This occurred in approximately 25 percent of the specimens tested. Also, the apparent precrack lengths estimated from force versus BFS data reasonably estimate the physical precrack length for materials without a microstructure (e.g., glass) or with a fine microstructure. For in situ toughened materials, force versus BFS data slightly underestimated the physical precrack length. Common operational procedures gave similar estimates of fracture toughness.

\section{References}

1. D. Munz, R. T. Bubsey, and J.L. Shannon, Jr., "Fracture Toughness Determination of $\mathrm{Al}_{2} \mathrm{O}_{3}$ using Four-Point-Bend Specimens with Straight-Through and Chevron Notches," J. Am. Ceram. Soc., 63 [5-6], 300-305 (1983).

2. J.A. Salem, L. Ghosn and M.G. Jenkins "Stress Intensity Factor Coefficients for Chevron-Notched Flexure Specimens and a Comparison Fracture Toughness Methods," Ceram. Eng. Sci. Proc. 20 [3], 503-512 (1999).

3. T. Nose and T. Fujii, "Evaluation of Fracture Toughness for Ceramic Materials by a Single-EdgePrecracked-Beam Method," J. Am. Ceram. Soc., 71 [5], 328-33 (1988).

4. R. Warren and B. Johannesson, "Creation of Stable Cracks in Hardmetals Using 'Bridge Indentation', Powder Metallurgy, 27 [1], 25-29 (1984).

5. J.J. Petrovic and M.G. Mendiratta, "Fracture from Controlled Surface Flaws," in Fracture Mechanics Applied to Brittle Materials, ASTM STP 678, S.W. Freiman ed., 83-102, 1979.

6. J.A. Salem, G.D. Quinn, M.G. Jenkins, "Measuring the Real Fracture Toughness of Ceramics: ASTM C1421," pp. 531-553 in Fracture Mechanics of Ceramics: Active Materials, Nanoscale Materials, Composites, Glass, and Fundamentals, R.C. Bradt, D. Munz, M. Sakai and K. White, eds., Springer, 2005.

7. "Standard Test Methods for Fracture Toughness of Advanced Ceramics," Test Method C1421, Annual Book of ASTM Standards, Vol. 15.01, West Conshohocken, PA, 2000.

8. F.I. Baratta and W.I. Dunlay, "Crack Stability in Simply Supported Four-Point and Three-Point Loaded Beams of Brittle Materials," Mechanics of Materials, 10, 149-159 (1990).

9. I. Bar-on, F.I. Baratta, and K. Cho, "Crack Stability and its Effect on Fracture Toughness of Hot Pressed Silicon Nitride Beam Specimens,” J. Am. Ceram. Soc., 79 [9], 2300-2308 (1996).

10. M. Mizuno and H. Okuda, VAMAS Round Robin on Fracture Toughness of Silicon Nitride at High Temperature, Technical Report No. 16, Japan Fine Ceramics Center, Nagoya, Japan, December 1993.

11. I. Bar-on and K. Cho," Crack Stability Analysis and Fracture Toughness of Ceramic Bend Bars with a Modified Circular Cross Section," Experimental Mechanics Vol. 36 104-111, June (1995).

12. W.G. Clark and S.J. Hudak, "Variability in Fatigue Crack Growth Rate Testing," J. Testing and Evaluation, 3 [6], 454-476, (1975).

13. J.A. Salem, M. Radovic, E. Lara-Curzio, G. Nelson, "Fracture Toughness of Thin Plates By the Double-Torsion Test Method," pp. 63-73 in Proceedings of the 28th International Cocoa Beach 
Conference on Advanced Ceramics and Composites: B, Ceramic Engineering and Science Proceedings, Vol. 25, No. 4, Waltraud M. Kriven and H.T. Lin, eds. (January 2006).

14. W.F. Deans and C.E. Richards, "A Simple and Sensitive Method of Monitoring Crack Extension and Load in Compact Fracture Mechanics Specimens Using Strain Gages," J. Testing and Evaluation, 7 [3], 147-154 (1979).

15. W.T. Riddell and R.S. Piascik, "A Back Face Strain Compliance Expression for the Compact Tension Specimen," NASA/TM-1988-208453 (1988).

16. J.A. Salem, L.J. Ghosn, and M. G. Jenkins "A Strain Gage Technique to Measure Stable Crack Extension in Ceramics," pp. 1-8 in the Proc. of the Soc. for Experimental Mechanics Spring Conference, June 2-4, 1997, Bellevue, WA.

17. J.A. Salem, L. Ghosn and M.G. Jenkins "Back-Face Strain as a Method for Monitoring Stable Crack Extension," Ceram. Eng. Sci. Proc. 9 [3], 587-594 (1998).

18. T. Fett, D. Munz, and G. Thun, "Method to Estimate Crack-Tip Toughness from Bending Tests on Prenotched Bars," J. Am. Ceram. Soc. 83, 421-423 (2000)

19. J.E. Srawley and B. Gross, in Cracks in Fracture, ASTM STP No. 601, American Society for Testing and Materials, West Conshohocken, PA., 1976.

20. T. von Karman and F. Seewald, Abh. Aerodynam. Inst., Tech. Hochs, (Aachen), 7, 3, 1927.

21. S. Timoshenko and J.N. Goodier, Theory of Elasticity, $2^{\text {nd }}$ ed. McGraw-Hill, N.Y., 117-119, 1951.

22. J. Kubler, "Fracture Toughness of ceramics Using the SEVNB Method: Preliminary Results," Ceram. Eng. Sci. Proc., 18 [4], 155-162 (1997).

23. J.A. Salem, N.N. Nemeth, L.M. Powers, and S.R. Choi, "Reliability Analysis of Uniaxially Ground Brittle Materials," J. Eng. for Gas Turbines and Power, Vol. 118, 863-871 (1996).

24. J.A. Salem, S.R. Choi, W.A. Sanders, D. Fox, "Elevated Temperature Mechanical Behavior of Monolithic and SiC Whisker Reinforced Silicon Nitrides, NASA Technical Memorandum 105245, 1991.

25. S.R. Choi and J.A. Salem, "Crack-Growth Resistance of in Situ-Toughened Silicon Nitride," J. Am. Ceram. Soc., 77 [4] 1042-46 (1994).

26. C.W. Li, and J. Yamanis, "Super-Tough Silicon Nitride with R-Curve Behavior," Ceram. Eng. Sci. Proc., 10, 632-645 (1988).

27. C. Betz, Principals of Penetrants, Magnaflux Corp., Chicago, Ill., 1969.

28. E.R. Fuller and B.R. Lawn, "Theory for Brittle Flaws Originating from Residual Stress Concentrations," J. Am. Ceram. Soc. 66 [5] 314-321 (1983).

29. J.A. Salem and R. Tandon, "Test Method Variability in Slow Crack Growth Properties of Sealing Glasses," International Journal of Fatigue, 32, 557-564, 2010.

30. Standard Test Method for Plane-Strain Fracture Toughness of Metallic Materials.” Test Method E399, Annual Book of ASTM Standards, Vol. 03.01, ASTM, West Conshohocken, PA, 1990. 


\begin{tabular}{|c|c|c|}
\hline \multicolumn{2}{|c|}{ REPORT DOCUMENTATION PAGE } & $\begin{array}{l}\text { Form Approved } \\
\text { OMB No. 0704-0188 }\end{array}$ \\
\hline \multicolumn{3}{|c|}{ 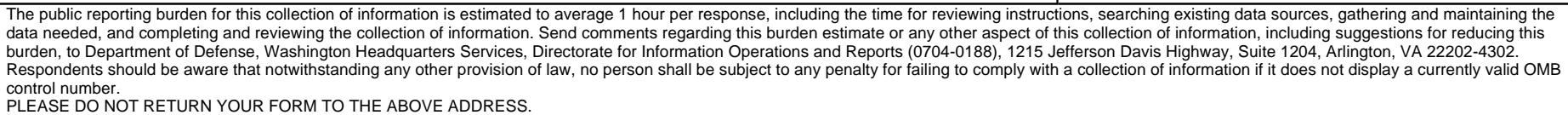 } \\
\hline $\begin{array}{l}\text { 1. REPORT DATE (DD-MM-YYYY) } \\
01-05-2010\end{array}$ & $\begin{array}{l}\text { 2. REPORT TYPE } \\
\text { Technical Memorandum }\end{array}$ & 3. DATES COVERED (From - To) \\
\hline \multirow{3}{*}{\multicolumn{2}{|c|}{$\begin{array}{l}\text { 4. TITLE AND SUBTITLE } \\
\text { Back-Face Strain for Monitoring Stable Crack Extension in Precrac }\end{array}$}} & 5a. CONTRACT NUMBER \\
\hline & & 5b. GRANT NUMBER \\
\hline & & 5c. PROGRAM ELEMENT NUMBER \\
\hline \multirow{3}{*}{\multicolumn{2}{|c|}{$\begin{array}{l}\text { 6. AUTHOR(S) } \\
\text { Salem, Jonathan, A.; Ghosn, Louis, J. }\end{array}$}} & 5d. PROJECT NUMBER \\
\hline & & 5e. TASK NUMBER \\
\hline & & $\begin{array}{l}\text { 5f. WORK UNIT NUMBER } \\
\text { WBS 441261.04.22.04.03 }\end{array}$ \\
\hline \multicolumn{2}{|c|}{$\begin{array}{l}\text { 7. PERFORMING ORGANIZATION NAME(S) AND ADDRESS(ES) } \\
\text { National Aeronautics and Space Administration } \\
\text { John H. Glenn Research Center at Lewis Field } \\
\text { Cleveland, Ohio 44135-3191 }\end{array}$} & $\begin{array}{l}\text { 8. PERFORMING ORGANIZATION } \\
\text { REPORT NUMBER } \\
\text { E-17278 }\end{array}$ \\
\hline \multirow{2}{*}{\multicolumn{2}{|c|}{$\begin{array}{l}\text { 9. SPONSORING/MONITORING AGENCY NAME(S) AND ADDRESS(ES) } \\
\text { National Aeronautics and Space Administration } \\
\text { Washington, DC 20546-0001 }\end{array}$}} & $\begin{array}{l}\text { 10. SPONSORING/MONITOR'S } \\
\text { ACRONYM(S) } \\
\text { NASA }\end{array}$ \\
\hline & & $\begin{array}{l}\text { 11. SPONSORING/MONITORING } \\
\text { REPORT NUMBER } \\
\text { NASA/TM-2010-216341 }\end{array}$ \\
\hline \multicolumn{3}{|c|}{$\begin{array}{l}\text { 12. DISTRIBUTIONIAVAILABILITY STATEMENT } \\
\text { Unclassified-Unlimited } \\
\text { Subject Categories: } 27 \text { and } 38 \\
\text { Available electronically at http://gltrs.grc.nasa.gov } \\
\text { This publication is available from the NASA Center for AeroSpace Information, 443-757-5802 }\end{array}$} \\
\hline
\end{tabular}

\section{SUPPLEMENTARY NOTES}

Submitted to the Journal of the American Ceramic Society.

\section{ABSTRACT}

Calibrations relating back-face strain to crack length in precracked flexure specimens were developed for different strain gage sizes. The functions were verified via experimental compliance measurements of notched and precracked ceramic beams. Good agreement between the functions and experiments occurred, and fracture toughness was calculated via several operational methods: maximum test load and optically measured precrack length; load at 2 percent crack extension and optical precrack length; maximum load and back-face strain crack length. All the methods gave vary comparable results. The initiation toughness, $K_{I i}$, was also estimated from the initial compliance and load.The results demonstrate that stability of precracked ceramics specimens tested in four-point flexure is a common occurrence, and that methods such as remotely-monitored load-point displacement are only adequate for detecting stable extension of relatively deep cracks.

\section{SUBJECT TERMS}

Fracture mechanics; Strain; Crack length; Stiffness; Stability; Silicon nitrides; Ceramics

\begin{tabular}{|c|c|c|c|c|c|}
\hline \multicolumn{3}{|c|}{ 16. SECURITY CLASSIFICATION OF: } & \multirow{2}{*}{$\begin{array}{l}\text { 17. LIMITATION OF } \\
\text { ABSTRACT } \\
\text { UU }\end{array}$} & \multirow{2}{*}{$\begin{array}{l}\text { 18. NUMBER } \\
\text { OF } \\
\text { PAGES } \\
27\end{array}$} & \multirow{2}{*}{$\begin{array}{l}\text { 19a. NAME OF RESPONSIBLE PERSON } \\
\text { STI Help Desk (email:help@sti.nasa.gov) } \\
\text { 19b. TELEPHONE NUMBER (include area code) } \\
\text { 443-757-5802 }\end{array}$} \\
\hline $\begin{array}{l}\text { a. REPORT } \\
U\end{array}$ & $\begin{array}{l}\text { b. ABSTRACT } \\
U\end{array}$ & $\begin{array}{l}\text { c. THIS } \\
\text { PAGE } \\
\text { U }\end{array}$ & & & \\
\hline
\end{tabular}



